Paweł Janik

Uniwersytet Warszawski, Warszawa

\title{
Rola koczowników Wielkiego Stepu w transferze idei pomiędzy Europą a Dalekim Wschodem
}

Wielki Step, czyli obszar trawiasty ciągnący się w przybliżeniu od Kotliny Karpackiej do Mandżurii, od wielu tysiącleci stanowił dom dla niezliczonych ugrupowań wędrownych pasterzy. I choć w powszechnej świadomości teren ten funkcjonuje często jako Dzikie Pola - nieprzyjazne miejsce zamieszkałe przez barbarzyńskie, krwiożercze ludy, to jednak wszystko wskazuje na to, że Wielki Step nie był barierą, lecz pomostem, a zamieszkujący go koczownicy pośrednikami pomiędzy dwoma skrajnymi obszarami Eurazji Europą i Dalekim Wschodem. Oczywiście proces „wędrówek” idei kulturowych nie ograniczał się tylko do tych dwóch obszarów. Do rejonów biorących bezpośrednio udział w powyższej wymianie idei można byłoby włączyć również m.in. tereny syberyjskie, osiadłe społeczności Azji Środkowej, Bliski Wschód oraz północne Indie. Jednak w niniejszym artykule skupię się jedynie na kontaktach kulturowych pomiędzy terenami europejskimi a Dalekim Wschodem, rozumianym tu głównie jako obszar cywilizacji chińskiej oraz Półwysep Koreański. Zakres chronologiczny tejże pracy mieści się pomiędzy III tys. p.n.e. a czasami tuż po najeździe mongolskim na Europę, który miał miejsce w drugiej dekadzie XIII w. n.e. Oczywiście kontakty pomiędzy wspomnianymi rejonami miały miejsce zarówno wcześniej, jak i później, jednakże te wcześniejsze 
zdarzały się bardzo sporadycznie ${ }^{1}$, a późniejsze zostały dobrze udokumentowane. W pracy tej nie będę wspominał o takich wynalazkach, które choć rozpowszechniły się na szerszą skalę dzięki kontaktom Wschodu $\mathrm{z}$ Zachodem (np. papier), to jednak $\mathrm{w}$ ich rozpropagowaniu nie brały udziału ludy koczownicze.

Pierwsze szersze kontakty pomiędzy zachodnią Eurazją a Dalekim Wschodem miały miejsce w okolicach przełomu III i II lub na początku II tysiąclecia p.n.e. i związane były z napływem ludności pasterskiej z zachodniej Syberii na tereny obecnego Xinjiangu. $\mathrm{Na}$ początku XX w. n.e. na pustyni Takla Makan zaczęto natrafiać na zmumifikowane szczątki ludzkie. Ich odkrywcami byli m.in. tacy podróżnicy jak Sven Hedin i Aurel Stein (Mallory 2000: 10). Po oględzinach okazało się, że część z nich reprezentuje europoidalny typ antropologiczny. Najstarsza $\mathrm{z}$ mumii pochodziła z Qäwrighu i została wydatowana na około 1800 r. p.n.e.. Pod względem antropologicznym wykazywała ona najbliższe podobieństwo do populacji zamieszkujących południową Syberię, Kazachstan oraz obszar dolnej Wołgi w epoce brązu (tamże: 237). W późniejszych czasach badania genetyczne potwierdziły, że spora cześć pochowanych tam ludzi miała przodków pochodzących z zachodniej Eurazji (Li 2010). Najmłodsze mumie pochodziły już z I tysiąclecia n.e. i można zauważyć, że im młodsze mumie, tym częściej występowały wśród nich cechy mongoloidalne, co zapewne było związane $\mathrm{z}$ mieszaniem się $\mathrm{z}$ azjatycką ludnością pochodzącą ze stepów Mongolii, Syberii oraz z Chin. Na datowanym na IX w. n.e. fresku z Bezeklik w Xinjiangu widać dwóch mnichów buddyjskich jednego mającego mongoloidalne cechy antropologiczne i drugiego reprezentującego typ europoidalny (Mallory 2010, fig. 1). Aurel Stein ponadto jako pierwszy odnalazł na terenie Xinjiangu fragmenty manuskryptów zapisanych $\mathrm{w}$ nieidentyfikowanych $\mathrm{w}$ tamtym czasie językach (Deuel 1970: 425-455). Teksty te w większości były zapisane $\mathrm{w}$ piśmie Brahmi na liściach palmowych, drewnianych tabliczkach oraz chińskim papierze, a datuje się je na okres od VI do VIII w. n.e. ${ }^{2}$ Po analizie lingwistycznej okazało się, że zapisano je w języku, a właściwie w co najmniej dwóch spokrewnionych ze sobą językach, należących do nieznanej wtedy gałęzi języków indoeuropejskich. Intrygujące jest to, że nie był on związany

1 Można tu wymienić m.in. migracje tzw. „człowieka z jaskini Denisowa” na obszarach leżących pomiędzy Ałtajem a Hiszpanią (Callaway 2013).

2 Choć pierwsze, pojedyncze słowa tocharskie pochodzą $\mathrm{z}$ dokumentów z Krorän datowanych na III w. n.e. i zapisanych w Prakrycie (Mallory 2000: 270-297). 
z językami indoirańskimi, obecnymi $\mathrm{w}$ późniejszym czasie $\mathrm{w}$ Azji Środkowej, a zdaniem niektórych badaczy najbliżej mu do języka hetyckiego i innych anatolijskich języków indoeuropejskich (Bouckaert 2012: 957-960). Friedrich W. K. Müller jako pierwszy zaproponował, by owe języki wiązać z ludem Tocharów (Mallory 2000: 270-297) wspominanym przez pisarzy antycznych takich jak Ptolemeusz (VI. 11. 6) czy Strabon (11. 8. 2). Tocharowie bywaja często utożsamiani ze znanym z chińskich źródeł ludem Yuezhi (Yuèzhī，月氏), który został pokonany przez Xiongnu (Xiōngnú, 匈 奴). Yuezhi opuścili swoje dotychczasowe siedziby w Xinjiangu i opanowali państwo greko-baktryjskie (Shiji 123), a w późniejszym czasie dali tam początek państwu kuszańskiemu. Odtąd byli oni nazywani „dużymi Yuezhi”, natomiast ci, co pozostali w dawnych siedzibach - „małymi Yuezhi” (Hanshu 96). Yuezhi mieli dostarczać Chińczykom jadeit i wygląda na to, że miało to długą tradycję, ponieważ w grobowcu Fuhao (妇好墓) z czasów dynastii Shang (商超) (XVI-XI w. p.n.e.) znaleziono duże ilości jadeitu pochodzącego z Chotan we współczesnym Xinjiangu (Lebedynsky 2006: 59). Utożsamienie Tocharów $\mathrm{z}$ Yuezhi wzięło się z tego, że według Strabona Tocharowie byli jednym $\mathrm{z}$ plemion, które opanowały Baktrię, a w późniejszym czasach kraina ta bywała nazywana Tocharystanem. Poza tym $\mathrm{w}$ tekstach staroturkijskich występuje wyraz twyry lub toxri na określenie ludności Kotliny Tarymskiej (Mallory 2000: 270-297), jednakże mieszkańcy tych terenów sami się w ten sposób nie określali. Oczywiście związek Tocharów z Yuezhi i językami indoeuropejskimi z kotliny Tarymskiej nie jest do końca pewny (choć najbardziej prawdopodobny), jednak powyższe języki mimo to są umownie nazywane tocharskimi. Owe języki oraz wspomniane wcześniej mumie europoidów, mimo pewnych rozbieżności chronologicznych ${ }^{3}$, można najprawdopodobniej połączyć ze sobą. Świadczą one o tym, że na terenach obecnego Xinjiangu co najmniej od początku II tysiąclecia p.n.e. (a prawdopodobnie i wcześniej) mieszkała ludność pochodząca najpewniej z zachodniej Eurazji. Osadnicy ci byli przypuszczalnie w dużej części wędrownymi pasterzami, którzy w nowej ojczyźnie przeszli w większości na rolnictwo oazowe. Dlaczego się tam znaleźli i czy są jakieś dowody

3 Najstarsze mumie pochodzą z początku II tysiąclecia p.n.e., natomiast najwcześniejsze zabytki języka tocharskiego z III w. n.e. Jednakże nie powinno to stanowić problemu, ponieważ $\mathrm{w}$ starszym okresie na danych terenach po prostu nie było możliwości zapisu języka, natomiast najmłodsze z mumii pochodzą już z czasów powstawania dokumentów w językach tocharskich. 
na ich wędrówkę? I w tym miejscu wskazówek udziela nam archeologia. Na terenie Kotliny Dżungarskiej, na obszarach leżących na północ od niej oraz w niektórych częściach Kotliny Tarymskiej (m.in. Qäwrighu), stwierdzono obecność kultury archeologicznej nawiązującej do kultury afanasjewskiej. Nawiązania te przejawiają się m.in. w formach naczyń i grobów, obecności antropomorficznych steli (Mallory 2010: 50-53) oraz w przedmiotach metalowych (Junli 2009: 202-203). Kultura afanasjewska była eneolityczną jednostką kulturową, rozwijającą się na terenach Kotliny Minusińskiej, Altaju i wschodniego Kazachstanu w okresie mniej więcej od 3300 do 23002000 p.n.e. (Svyatko 2009: 266). W jej genezie, oprócz miejscowego podłoża, miały udział elementy kulturowe ze wschodniej Europy (kultura grobów jamowych). Owa jednostka kulturowa powstała zapewne na skutek migracji ludności wschodnioeuropejskiej na tereny Kotliny Minusińskiej oraz Ałtaju i połączenia się ich z miejscowym substratem etnicznym (Matušenko 1997: 43-45). Ludność tej kultury zapoczątkowała po raz pierwszy na omawianych terenach gospodarkę wytwórczą (hodowla krów, koni i owiec oraz rolnictwo), a także obróbkę miedzi. Ta jednostka kulturowa ekspandowała także na sąsiednie terytoria, takie jak obszary współczesnej Mongolii i Xinjiangu, co zostało zasygnalizowane wyżej, oraz oddziaływała na wczesną chińską metalurgię. Na przełomie III i II tysiąclecia p.n.e. kultura afanasjewska zaczęła być zastępowana przez kulturę andronowską i karasuską. To prawdopodobnie wtedy przodkowie późniejszych Tocharów zaczęli przenosić się na tereny współczesnego Xinjiangu, co zgadzałoby się z datowaniem najstarszych mumii z Kotliny Tarymskiej. Jednakże możliwe, że część z nich pozostała na dawnych terenach, ponieważ pewne kulturowe elementy postneolityczne dalej trwały w Kotlinie Minusińskiej, a w późniejszym czasie brały udział razem z kulturą andronowską i karasuską w powstaniu kultury tagarskiej (VIII-III w. p.n.e.) (Chochorowski 1999b: 351). Z jednostki tej powstała kultura tasztycka (II w. p.n.e.-V w. n.e.), która wiązana jest z tzw. Kirgizami jenisejskimi. Chińskie źródła pisane z czasów dynastii Tang (唐朝, VII-X w. n.e.) m.in. Kronika zachodnich rejonów opisują owych Kirgizów jenisejskich (Gekun, 鬲昆, Jiegu, 结骨) jako ludzi o przeważnie rudych włosach i niebieskich oczach. Natomiast ci o czarnych oczach, byli rzekomo potomkami chińskiego generała Li Linga (李陵) (Findley 2004: 118, Lung 2011: 108). Oczywiście owi Kirgizi o bardziej mongoloidalnym wyglądzie byli prawdopodobnie potomkami miejscowej, syberyjskiej ludności lub mieli mieszane pochodzenie. Faktycznie, badania genetyczne wskazują na to, że 
ludność kultury tasztyckiej stanowiła mieszankę przybyszów z zachodniej Eurazji i miejscowych autochtonów (Keyser 2009: 395410). Oczywiście nie jesteśmy w stanie stwierdzić, jakim językiem lub jakimi językami mówili twórcy tej kultury - indoeuropejskimi (tocharskimi lub irańskimi), ałtajskimi czy innymi rdzennie syberyjskimi. Współcześni Kirgizi mówią językiem $\mathrm{z}$ rodziny turkijskiej, jednak nie zawsze musiało tak być. Mieszając się z miejscową ludnością, mogli przejmować jej język oraz cechy antropologiczne. Współcześni Kirgizi zamieszkujący Kirgistan oraz Chakasi zamieszkujący Kotlinę Minusińską są w większości raczej mongoloidalni, jednak badania genetyczne potwierdzają występowanie u bardzo dużej ich części haplogrupy R1a1 (Zerjal 2002: 466-482), która jest charakterystyczna dla mieszkańców zachodniej Eurazji. Kirgizi odziedziczyli ją zapewne po przodkach pochodzących z tamtych rejonów.

Jak już zostało to wcześniej zasygnalizowane, jedne z pierwszych chińskich przedmiotów metalowych, m.in. z kultury Qijia (24001900 p.n.e.), nawiązują do pierwowzorów z kultury afanasjewskiej oraz innych rejonów zachodniej i centralnej Eurazji (Junli 2009: 202203, 206). Nie jest jednak pewne, czy poprzez kontakt z tymi ludami, będącymi zapewne protoplastami tzw. „Tocharów”, przodkowie Chińczyków Han przejęli samą umiejętność obróbki metalu, ponieważ dwa najstarsze przedmioty metalowe $\mathrm{z}$ terenu późniejszych Chin znalezione w kontekście kultury Majiayao (3100-2700 p.n.e.) nie wykazują podobieństwa do zabytków z euroazjatyckiego stepu (tamże: 203). Nawet jeśli tak było, to wcześni Chińczycy metalurgię tę rozwinęli i zaawansowaniem wkrótce przewyższyli samych nomadów (Bavarian 2006: 9-10). Można byłoby wtedy mówić o swoistym sprzężeniu zwrotnym, choć zaznaczam, że nie jest to pewne. Mniej więcej w tym samym czasie przodkowie Chińczyków przejęli od nomadów umiejętność hodowli konia oraz znajomość rydwanu. Od tej pory Chińczycy pożądali koni pochodzących od ludów z północy i zachodu, czego przykładem może być niezwykłe uwielbienie za czasów dynastii Han (汉朝, III w. p.n.e.-III w. n.e.) rumaków pochodzących z Fergany (Gafurow 1978: 149-150). Najstarsze rydwany pochodzą z kultury grobów katakumbowych (2800-2000 p.n.e.) (Chochorowski 1999a: 269), jednakże były one używane również w kulturze afanasjewskiej (Mallory 2010: 52). Natomiast na obszarze historycznych Chin konie i rydwany pojawiły się w drugiej połowie III tysiąclecia p.n.e. Najstarsze szczątki koni pochodzą ze wspomnianej już kultury Qijia (Cosmo 1999: 901), a niewiele później umiejętność hodowli tego zwierzęcia rozpowszechniła się na obszary rdzennie chińskie (dolne dorzecze Rzeki Żółtej i Jangcy). 
Wszystkie wymienione wyżej elementy, tj. dane archeologiczne, zabytki języków „tocharskich” i mumie z Kotliny Tarymskiej oraz dane antropologiczne i genetyczne świadczą o tym, że owi „Tocharzy” faktycznie byli ludem indoeuropejskim, którego przodkowie pochodzili z zachodniej Eurazji i którzy gdzieś na przełomie III i II tysiąclecia p.n.e. osiedlili się na terenie współczesnych zachodnich Chin.

Języki tocharskie z Kotliny Tarymskiej prawdopodobnie od IX w. n.e. zaczęły być wypierane przez język ujgurski. Ciekawostką jest to, że pewne znane teksty $\mathrm{w}$ języku ujgurskim są przekładami ze starszych tekstów tocharskich (Mallory 2010: 44-53). Ujgurzy poza wierzeniami i literaturą przejęli także inne elementy kulturowe ludności miejscowej, w tym rolnictwo oazowe. W związku z tym można stwierdzić, że istniała i dalej trwa pewna forma ciągłości kulturowej, a dawni mieszkańcy zmieszali się z Ujgurami i ludnością Han, przejmując ich tożsamość etniczną. Ta asymilacja jest widoczna u współczesnych mieszkańców Kotliny Tarymskiej i przejawia się w występowaniu u wielu Ujgurów europoidalnych cech antropologicznych, o czym świadczą również badania genetyczne (Xu 2008: 883-889).

W kolejnych wiekach kontakt kultury chińskiej i ugrupowań koczowniczych z obszaru północnych i zachodnich współczesnych Chin $\mathrm{z}$ nomadami z zachodniej i środkowej Eurazji trwał dalej. W I tysiącleciu p.n.e. objawia się to $\mathrm{w}$ występowaniu na powyższych obszarach elementów kultury scytyjskiej w tym zoomorficznego stylu syberyjskiego (Junli 2009: 3-4, 26, 206, Feltham 2010: 1-28).

Omawiając kontakty zachodniej Eurazji z Dalekim Wschodem, trzeba oczywiście wspomnieć o tzw. jedwabnym szlaku, czyli sieci dróg handlowych, zarówno morskich, jak i lądowych, które łączyły m.in. Europę z Azją Wschodnią. Trzeba zaznaczyć, że jedwab był tylko jednym $\mathrm{z}$ rodzajów towarów, które uczestniczyły $\mathrm{w}$ tej wymianie handlowej. Tradycyjnie za początek historii jedwabnego szlaku uważa się podróż emisariusza chińskiego Zhang Qiana (张骞) na zachód. Wyprawa ta miała miejsce w latach 138-125 p.n.e., a celem wysłannika było odnalezienie i przekonanie Wielkich Yuezhi (大月氏), którzy w tym czasie osiedli w Baktrii, żeby wspomogli cesarza chińskiego Wudi z dynastii Han (汉武帝) w walce z Xiongnu. Yuezhi odmówili, niemniej jednak Zhang Qian przywiózł do Chin mnóstwo informacji na temat zachodnich krain oraz w pewnym sensie zainicjował kontakt cesarstwa Hanów z zachodem (Boulnois 2005: 66). Choć w zespołach archeologicznych wiązanych z koczownikami znajdowany jest jedwab, a nomadzi ci mogli 
w jakimś stopniu uczestniczyć w wymianie handlowej, to jednak nic nie wskazuje, by $\mathrm{w}$ tych kontaktach odgrywali istotną rolę (Simonenko 2012: 295). Aczkolwiek w danym zagadnieniu istnieje jedna frapująca kwestia. Pozostałości jedwabnych tkanin pochodzących z terenu Europy są datowane na VI-V w. p.n.e., czyli na okres znacznie poprzedzający funkcjonowanie jedwabnego szlaku. Znaleziska te pochodzą z dwóch kurhanów kultury halsztackiej w Hochdorf i Hochmichele datowanych na VI w. p.n.e. oraz z grobu Kerameikos w Atenach datowanego na V w. p.n.e. (Barber 1992: 204). Rodzi się pytanie: $w$ jaki sposób materiały te dostały się do Europy? Nic nie wskazuje na to, by w tym czasie jedwab produkowano poza Chinami, a na pewno nie w Europie, do której technika jego wykonania dotarła dopiero w VI w. n.e. (Wojna Wandalska 4. 17). Nie istniały wtedy państwa hellenistyczne, które mogłyby odgrywać rolę pośredników i nie ma dowodów na to, by Imperium Achemenidzkie miało jakikolwiek kontakt z Chinami. Być może pośrednictwo Indii mogłoby wchodzić tu w grę, jednak to droga bardzo okrężna. Bardziej prawdopodobne wydaje się, że powyższe tkaniny jedwabne mogły dotrzeć do Europy wraz z nomadami (Barber 1992: 205). Był to czas, kiedy ugrupowania scytyjskie z Europy Wschodniej utrzymywały kontakt ze swoimi pobratymcami z Ałtaju i Syberii. Natomiast tamte plemiona miały kontakt z cywilizacją chińską. Oczyścicie nie mógł być to napływ jedwabiu ani w ogóle wymiana handlowa na taką skalę jak w czasach jedwabnego szlaku, ale jest to bardzo prawdopodobne. Twierdzeniu temu sprzyja fakt, że kultura halsztacka, z którą identyfikowane są wspomniane kurhany powstała pod wpływem silnych impulsów koczowniczych (Chochorowski 1999b: 361-363). Tak więc przedstawiciele elit kultury halsztackiej oraz Grecy mogli otrzymać owe tkaniny jedwabne poprzez pośrednictwo koczowników ze wschodniej Europy i Niziny Węgierskiej.

Koczownicy wschodnioeuropejscy, zapewne dzięki pośrednictwu środkowoazjatyckich nomadów $\mathrm{w}$ późnym okresie przedrzymskim i okresie wpływów rzymskich, mieli w dalszym ciągu kontakt z cywilizacją chińską, choć nadal dość ograniczony. Jednym z takich elementów przyniesionym $\mathrm{z}$ Chin były miecze $\mathrm{z}$ pierścieniowatą głowicą. W archeologicznych zespołach sarmackich spotyka się je od I p.n.e. do II n.e., natomiast w I w. n.e. ten typ oręża przejęli Rzymianie oraz inne ludy, $\mathrm{z}$ tym że ich naśladownictwa różniły się konstrukcyjnie od oryginałów (Skripkin 2003: 9-18). Także jadeitowe zdobienia rękojeści mieczy oraz pochwy ornamentowane stylem geometrycznym były chińskim zapożyczeniem i użytkowane były 
w środowisku wschodnioeuropejskich, irańskojęzycznych nomadów mniej więcej od I do III w. n.e. Przedmiotami takimi były również chińskie brązowe lustra, które nierzadko są odnajdywane w grobach sarmackich i alańskich z drugiej połowy I i II w. n.e. Należały one do najróżniejszych typów, w tym TLV. Znamienite są również znaleziska marmurowego i alabastrowego moździerza z grobów sarmackiej elity na terenie współczesnej Ukrainy i rejonu dolnej Wołgi. Zdobione są one chińskim meandrem, natomiast egzemplarz z Ukrainy ma dodatkowo uchwyty w kształcie zajęcy (Simonenko 2012: 297). Ozdobienie moździerza zajęczymi rączkami związane jest z mitem o Chang'e (嫦娥). Była ona żoną łucznika Hou Yi (后渂), który kiedyś otrzymał od bogini Xīwangmu (西王母) dwa eliksiry nieśmiertelności sporządzone przez zające mieszkające na Księżycu ${ }^{4}$. Chang'e wypiła omyłkowo dwa naraz, stając się boginią Księżyca (Allan 2012: 80). W sztuce ukazywana jest ona czasami z towarzyszącymi jej zającami, które w moździerzach wyrabiają napój nieśmiertelności.

Jeszcze innym ważnym elementem w kulturze sarmackiej zaczerpniętym $\mathrm{z}$ Chin, zapewne $\mathrm{w}$ II lub I w. p.n.e., jest przedstawienie podłużnego, żmijopodobnego smoka (Simonenko 2012: 290), które dało początek sarmackiemu symbolowi drako. Wyobrażenie to pochodzi od istot z mitologii chińskiej zwanych lóng (龙). Na początku takie przedstawienie smoka w sztuce sarmackiej występowało na płytkach będących okuciami pasa, lecz później przerodziło się $\mathrm{w}$ rodzaj sztandaru, na którego włóczni umieszczano figurę smoka. Następnie w I w. n.e. symbol ten przejęli Dakowie, a w II w. n.e. Rzymianie. Drako używano aż do średniowiecza - jest widoczny m.in. na tkaninie z Bayeux. Na wyspy brytyjskie symbol ten przywędrował wraz z sarmackimi Jazygami, którzy w ramach traktatu z Rzymianami w liczbie 5500 po 170 r. n.e. zostali przesiedleni na teren rzymskiej Brytanii. Było to związane $\mathrm{z}$ ich udziałem w wojnach markomańskich po stronie przeciwników Cesarstwa Rzymskiego. Zostali oni osiedleni m.in. w okolicy Wału Hadriana w obrębie twierdz Bremetennacum (współczesne Ribchester) oraz Deva Vitrix (współczesne Chester), gdzie później zasymilowali się $\mathrm{z}$ miejscową ludnością. W Chester odnaleziono przedstawienie jeźdźca sarmackiego trzymającego drako, które ma analogię m.in. w Tanais (Mihailescu-Bîrliba 2009: 146-154). Istnieją przypuszczenia, że symbol ten dał początek godłu Walii oraz że

${ }^{4}$ W Chińskich legendach zające/króliki miały zamieszkiwać Księżyc. Jest to związane $\mathrm{z}$ tym, że ukształtowanie powierzchni Księżyca widoczne z ziemi może przypominać zająca/królika stojącego przy jakimś przedmiocie (np. moździerzu). 
mityczny król Arthur oraz jego rycerze okrągłego stołu mogli być potomkami owych Jazygów. Przydomek rodowy legendarnego króla Brytów Pendragon miał być nawiązaniem do sztandaru drako (Nicolle 1984: 35-41). Oczywiście jest to tylko luźna hipoteza, bez bardziej znaczących dowodów.

Niektórzy uważają, że siodła z wysokimi łękami także dotarły do Europy z Dalekiego Wschodu, a pośredniczyć w tym mieli Hunowie ${ }^{5}$. Choć inni badacze wskazują, że Rzymianie używali tej części rzędu końskiego posiadającej łęki (tzw. cztery rogi) od I w. p.n.e. (Gawroński 2004: 31-40), to jednak różniły się one od typowych siodeł z wysokimi łękami. Pierwsze tego typu przedmioty, z których wywodzą się współczesne siodła, pojawiły się na terenie Chin i Korei w IV w. n.e. Natomiast najstarsze prawdziwe siodła $\mathrm{z}$ wysokimi łękami pochodzą z czasów depozytów archeologicznych łączonych z Hunami, m.in. z grobu Pécs-Üszög (Dąbrowski 1975: 57).

We wczesnym średniowieczu ludem stepowym, który wprowadził wiele elementów pochodzących z Dalekiego Wschodu, byli Awarowie. Prawdopodobnie wywodzili się ze związku plemiennego księżniczki Ruru (蠕蠕) z plemienia Rouran zamieszkałego na północ od Chin w okresie od IV do połowy VI w. n.e. Rouran zostali rozbici przez Türków, a część plemion, która nie chciała podporządkować się nowej władzy, wyemigrowała na zachód. Byli to zapewne Awarowie, którzy w Europie pojawiają się w 558 r. n.e., przynosząc ze sobą wiele elementów rodem z Azji Wschodniej, głównie militaria (Szymański 1979: 27-32). Były to m.in. hełmy lamelkowe, pałasze z pierścieniowatą głowicą, szable oraz strzemiona, które całkowicie zmieniły oblicze pól bitewnych Europy. Nawet jeśli nie wszystkie one dotarły z Awarami, to jednak ten lud przyczynił się do ich rozpowszechnienia $\mathrm{w}$ Europie. Hełmy lamelkowe pojawiły się po raz pierwszy $\mathrm{w} 2$. połowie $\mathrm{V}$ w. n.e. $\mathrm{w}$ Korei, natomiast pierwsze egzemplarze europejskie datowane są na VI w. n.e. i pochodzą z terenów Krymu i Niemiec. Najstarsze egzemplarze pałaszy z pierścieniowatą głowicą również zostały znalezione na terenie Korei i datowane są na przełom V i VI w. n.e., zaś pierwsze okazy europejskie pochodzą z VII w. n.e. Azjatycką genezę ma prawdopodobnie także szabla, choć najstarsze egzemplarze pochodzą z terenu Węgier, są datowane na VII-VIII w. n.e. i wiązane $\mathrm{z}$ Awarami. Ostatnim elementem dalekowschodnim przybyłym $\mathrm{z}$ Awarami, o którym

5 Pochodzenie samych Hunów jest przedmiotem wielu sporów od połowy XVIII w., więc nie będę tutaj poruszał tej kwestii, lecz odsyłam czytelnika do najobszerniejszej syntezy wiedzy o tym ludzie (Mèanchen-Helfen 1973). 
chciałem wspomnieć, są strzemiona. Choć istnieją przypuszczenia, że w czasach starożytnych mogły być używane strzemiona pętelkowe w formie sznurów. Przedmioty przypominające strzemiona są widoczne m.in. na tzw. gemmie kuszańskiej (Jankowski 2013: 534) oraz datowanym na I w. p.n.e. reliefie z Mathury w Indiach (Świętosławski 1990: 21). Jednakże najstarsze poświadczone okazy prawdziwych strzemion ${ }^{6}$ pochodzą $\mathrm{z}$ terenu historycznej Korei oraz przylegającego do niej pogranicza chińskiego i są datowane na IV w. n.e. Przedmioty te szybko zostały przejęte przez środowisko koczowników i najprawdopodobniej wraz z Awarami dotarły do Europy w 2. połowie VI w. n.e. Najstarsze egzemplarze strzemion pochodzą z cmentarzysk awarskich i datowane są na początek VII w. n.e. (Świętosławski 2001: 76-83).

Innym elementem łączącym koczowników wschodnioeuropejskich z Dalekim Wschodem jest kalendarz zwierzęcy pochodzenia chińskiego zawarty w tzw. Imienniku chanów bułgarskich (Lang 1983: 35, 38). Dzieło to wymienia pierwszych władców bułgarskich, lata ich panowania oraz przynależność rodową. Najstarsza znana kopia tego dokumentu pochodzi z XV w. n.e., ale niewątpliwie jest ona odpisem wcześniejszych wersji. Zawarty w owym Imienniku system liczenia dat opiera się na kalendarzu wzorowanym na chińskim pierwowzorze, który został przejęty przez różne ludy tureckie i mongolskie. Protobułgarzy odziedziczyli go prawdopodobnie po swoich huńskich protoplastach bądź przejęli od innych ludów koczowniczych. Kalendarz ten różni się jednak od swojego dalekowschodniego „przodka” kilkoma detalami.

Kolejnym elementem z kultury koczowników mającym głębokie korzenie $\mathrm{w}$ zachodniej Eurazji jest ich rodzime pismo - zwane pismem orchońskim lub runami tureckimi. Było ono używane m.in. przez Türków z Kaganatu Starotureckiego, Protobułgarów (zarówno nadwołżańskich, jak i naddunajskich), prawdopodobnie Awarów (zostało stwierdzone na naczyniu ze skarbu z Nagyszentmiklós), Turkijczyków (Turków środkowoazjatyckich), Chazarów oraz Węgrów. Wśród siedmiogrodzkich Seklerów (węg. Székely) pismo to przetrwało do XVIII w. n.e. (Everson 2012: 2-3), a i współcześnie istnieją osoby amatorsko tworzące $\mathrm{w}$ tej formie zapisu. Najstarsze dobrze datowane przykłady tego pisma pochodzą z VIII w. n.e., ale wiele wskazuje, że było ono używane dużo wcześniej. Niektóre przedmioty znalezione $\mathrm{w}$ kurhanach $\mathrm{w}$ Noin Uła były zdobione bardzo podobnymi, a czasem wręcz identycznymi znakami (Ishjatms

\footnotetext{
${ }^{6} \mathrm{Tj}$. sztywnych, zamkniętych pałąków, zawieszonych przy siodle na tzw. puśliskach.
} 
1996: 166). Zresztą o używaniu przez Xiongnu pisma wspomina Sima Qian (Shǐjì 110). Istnieją także poszlaki wskazujące na to, że Hunowie Europejscy również mogli znać ten typ zapisu (Dąbrowski 1975: 120). Pismo to wyewoluowało najprawdopodobniej z pisma Kharosthi, którego korzenie tkwią w alfabecie aramejskim (Ishjatms 1996: 166), czyli w zachodniej Eurazji. W datowanym na III w. p.n.e. kurhanie Esik $^{7}$ z południowo-wschodniego Kazachstanu oprócz części stroju i szczątków tzw. złotego człowieka odnaleziono naczynie $\mathrm{z}$ wyrytą na nim inskrypcją. Inskrypcja jest zapisana $\mathrm{w}$ piśmie Kharosthi, jednak bardzo stylizowanym - przypominającym już bardzo znaki z Noin Uła i runy tureckie. Język, który został w nim zapisany, to język sakijski, a sama inskrypcja stanowi najprawdopodobniej przepis kulinarny (Harmatta 1999: 421). Ludy ałtajskie najwidoczniej przejęły ową formę zapisu, dostosowując ją do swoich języków poprzez modyfikację kształtów liter, a następnie rozpowszechniły je na olbrzymich obszarach Eurazji.

Do najbardziej spektakularnych wynalazków, które mogły trafić do Europy z Dalekiego Wschodu za pośrednictwem koczowników, należały proch strzelniczy i broń palna. Choć ich geneza w Europie nadal nie jest jasna, to nie ulega wątpliwości, że rzeczy te pojawiają się po raz pierwszy w Chinach. Pierwsza wzmianka o prochu palnym pochodzi z taoistycznej pracy Zhēn yuán miào dào yàolù (真元妙道要 路) $\mathrm{z}$ połowy IX w. n.e., natomiast najstarsza formuła jego sporządzania została zawarta w militarnym kompendium Wǔjing Zǒngyào (武经总要) z 1044 r. n.e. (Chase 2003: 32-33). Wbrew obiegowej opinii, Chińczycy szybko odkryli jego zastosowanie nie tylko $\mathrm{w}$ fajerwerkach, ale także $\mathrm{w}$ wojsku. Pierwszą bronią palną były tzw. ogniste lance będące bezlufową bronią miotającą odłamkami metalu. Najstarsze przedstawienie tego typu oręża widnieje na jedwabnej tkaninie z Dunhuang. Widać na niej atakujące Buddę demony, trzymające $w$ rękach granaty i ogniste lance. Pierwszą wzmianką o użyciu tego typu broni jest opis oblężenia De'an, kiedy wojska chińskie użyły jej przeciwko Dżurdżenom (Needham 1986: 8-9, 222). Najstarsze przedstawienie broni lufowej zostało uwiecznione na XII-wiecznej rzeźbie z jaskini w Syczuanie. Przedstawia ono postać trzymającą wazopodobną bombardę oraz okrągły pocisk gotowy do załadowania. Natomiast najstarszy

7 Mogiła ta w literaturze występuje często pod błędną nazwą Issyk. Tymczasem prawidłowa nazwa tego stanowiska powinna być tłumaczona jako Kurhan Esik (kaz. Есік обасы). Serdecznie dziękuję recenzentowi za zwrócenie uwagi na kwestię prawidłowego nazewnictwa. 
zachowany egzemplarz broni lufowej pochodzi z Harbinu i datowany jest na 1288 r. n.e. (Chase 2003: 31-32, Needham 1986: 293-294). Jeśli chodzi o pojawienie się tego typu broni i prochu palnego w Europie, to istnieją różne zdania. Wedle niektórych zostały one wymyślone niezależnie albo też przybyły do Europy przez Bliski Wschód. Jednak prawdopodobnie zarówno proch, jak i broń palna pojawiły się w Europie w czasie inwazji mongolskiej w XIII w. n.e. Mongołowie użyli tego typu broni w bitwie na równinie Mohi w Siedmiogrodzie 11 kwietnia 1241 r. n.e. Pierwsza wzmianka o prochu strzelniczym pochodzi z Epistola de secretis operibus artiis et naturae autorstwa Rogera Bacona z 1267 r. n.e. Znamienny jest fakt, że był on przyjacielem Wilhema z Rubruk, który posłował na dwór Mongolski w latach 1253-1255 n.e. (Chase 2003: 58). Z kolei najstarsze przedstawienie ikonograficzne broni palnej w Europie pochodzi z manuskryptu De Nobilitatibus sapientii et prudentiis regum autorstwa Waltera de Milemete z 1326 r. n.e. (Kelly 2004: 29).

Dziedzictwem mongolskim w Europie może być nie tylko wprowadzenie prochu i broni palnej. Istnieje przypuszczenie, że takie nazwy krain dawnej Rusi jak Ruś Biała, Ruś Czarna i Ruś Czerwona powstały w czasach dominacji mongolskiej w Europie Wschodniej i wywodzą się z tradycji chińskiej. Nie jest tajemnicą, że Mongołowie w czasie podbojów korzystali $\mathrm{z}$ umiejętności inżynierów, rzemieślników, artystów, ludzi wykształconych oraz ogólnie z dóbr kulturalnych podbitych krajów, w tym Chin. W kulturze chińskiej kierunki świata są utożsamiane z pewnymi mitycznymi zwierzętami i kolorami: północ jest wiązana z czarnym żółwiem - Xuán Wǔ (玄 武), południe z czerwonym ptakiem (feniksem) - Zhū Què (朱雀), wschód z lazurowym smokiem - Qīng Lóng (青䴖), natomiast zachód z białym tygrysem - Bái Hǔ (白虎) (Csikszentmihalyi 2008: 908911). Również $w$ językach ałtajskich kolor czarny jest utożsamiany z północą. Co ważne, nazwy „kolorowych” Rusi pojawiają się dopiero po najeździe mongolskim. Po raz pierwszy nazwy Ruś Biała (Albae Russiae) użył pod rokiem 1381 n.e. w kronice Janko z Czarnkowa. Fragment ten opisywał uwięzienie Jagiełły ${ }^{8}$ jego matki w Połocku (Vauchez 2001: 163). Także położenie Rusi Czerwonej i Czarnej faktycznie pokrywa się z kierunkami znanymi z tradycji chińskiej. Ruś Biała jest tutaj pewnym wyjątkiem, ale może to wynikać ze złej orientacji przestrzennej dawnych geografów lub nadania jej nazwy

8 Chodzi oczywiście o późniejszego Władysława II Jagiełłę (imię Władysław otrzymał na chrzcie), późniejszego króla Polski, będącego jednak wtedy jeszcze tylko wielkim księciem litewskim. 
$\mathrm{w}$ innym okresie.

$\mathrm{Na}$ zakończenie chciałbym wspomnieć o jeszcze jednym elemencie, który mógł zostać wprowadzony do Europy przez Mongołów, choć jest to bardziej przypuszczenie niż teoria - chodzi mianowicie o pierogi. W tym przypadku istnieje bardzo niewiele źródeł, aczkolwiek ten rodzaj potrawy faktycznie pojawia się po raz pierwszy na Dalekim Wschodzie. W grobie nr 339 w Astanie w Kotlinie Turfańskiej odnaleziono dobrze zachowane egzemplarze pierożków w postaci, którą współcześni Chińczycy nazywają jiăozi (饺子). Pochówek ten datowany jest na czasy dynastii Tang (VII-X w. n.e.) (Xinjiang Uigur Autonomous Region Museum 2006: 112). Sprawą dyskusyjną jest, czy był to wynalazek chiński, czy też miejscowy. Żródła pisane wspominają o pierogach dopiero w czasach dynastii Song (宋朝, X-XII w. n.e.) (Davidson 2006: 267). Możliwe, że rozpowszechnienie tego typu potrawy na rozległych obszarach Eurazji miało miejsce w czasach ekspansji mongolskiej (Lane 2004: 89). Jest to oczywiście tylko luźna hipoteza. Smakiem pierogów zachwycał się św. Jacek Hiacynt Odrowąż w czasie pobytu w Kijowie, gdzie przebywał od 1128 do 1233 r. n.e. Z tym świętym związana jest legenda, wedle której po najeździe tatarskim na południową Polskę miał on karmić ubogich pierogami własnej roboty i dlatego zyskał przydomek „św. Jacek z pierogami” (Tatara 2012: 21).

Podsumowując, oprócz zniszczenia i terroru, plemiona koczownicze ze stepów euroazjatyckich miały także niewątpliwe zasługi w historii świata. Ludy takie jak m.in. „Tocharowie”, Scytowie, Sarmaci, Hunowie, Awarowie, Turcy i Mongołowie przyczyniły się do rozpowszechnienia wynalazków i idei, które może nie zawsze były ich własną inwencją, ale na pewno wpłynęły na kształt dziejów. Bez nich współczesny świat z pewnością nie byłby taki sam.

\section{Bibliografia}

Allan, Tony, Charles Phillips. 2012. Ancient China's Myths and Beliefs. Nowy Jork: Rosen Publishing.

Barber, Elizabeth. 1992. Prehistoric Textiles: The Development of Cloth in the Neolithic and Bronze Ages with Special Reference to the Aegean. New Jersey: Princeton University Pres.

Bavarian, Behzad, Lisa Reiner. 2006. Piece Mold, Lost Wax \& Composite Casting Techniques of the Chinese Bronze Age. Los Angeles: California State University Northridge. 
Bouckaert, Remco, Philippe Lemey (i in.). 2012. Mapping the Origins and Expansion of the Indo-European Language Family, Science 337, 957-960.

Boulnois, Luce. 2005. Silk Road: Monks, Warriors \& Merchants. Hongkong: Odyssey Books.

Chase, Kenneth. 2003. Firearms: A Global History to 1700. Cambridge: Cambridge University Press.

Chochorowski, Jan. 1999a. Łowcy i pasterze w dobie brązowego oręża - epoka brązu na obszarach Eurazji: Janusz K. Kozłowski (red.). Prehistoria - encyklopedia historyczna świata. Vol. 1. Kraków: Agencja Publicystyczno-Wydawnicza Opres, 253-303.

Chochorowski, Jan. 1999b. Żelazny oręż barbarzyńców - wczesna epoka żelaza poza zasięgiem cywilizacji klasycznych: Janusz K. Kozłowski (red.). Prehistoria - encyklopedia historyczna świata. Vol. 1. Kraków: Agencja Publicystyczno-Wydawnicza Opres, 304-395.

Cosmo, Nicola Di. 1999. The Northern Frontier in Pre-Imperial China: Michael Loewe, Edward L. Shaughnessy (red.). The Cambridge History of Ancient China: From the Origins of Civilization to 221 BC. Cambrige: Cambridge University Press, 885-966.

Csikszentmihalyi, Mark. 2008. Siling - 四灵 - Four Numina: Fabrizio Pregadio (red.). The Encyclopedia of Taoism. Vol. 1. Londyn: Routledge, 908-911.

Davidson, Alan. 2006. The Oxford Companion to Food. Oxford: Oxford University Press.

Dąbrowski, Krzysztof. 1975. Hunowie europejscy: Edward Tryjarski (red.). Hunowie europejscy, Protobułgarzy, Chazarzy, Pieczyngowie, Wrocław, Warszawa: Zakład Narodowy im. Ossolińskich, 10-152.

Deuel, Leo. 1970. Testaments of Time. Nowy Jork: Alfred A. Knopf.

Feltham, Heleanor. 2010. Nomad Culture, Greek Style: Steppes Jewellery and Adornment, Sino-Platonic Papers 205, 1-31.

Findley, Carter. 2004. The Turks in World History. Nowy Jork: Oxford University Press.

Gafurow, Bobodżan. 1978. Dzieje i kultura ludów Azji Centralnej. Warszawa: Państwowy Instytut Wydawniczy.

Gawroński, Radosław. 2004. Some Remarks on the Origins and Construction of the Roman Military Saddle, Archeologia 55, 31-40.

Ishjatms, Nyambuugiin. 1996. Nomads in Eastern Central Asia: János Harmatta (red.). History of Civilizations of Central Asia Vol. 2. Paryż: Unesco Publishing, 151-169.

Jankowski, Henryk. 2013. Altaic Languages and Historical Contact: Kim Juwon, Ko Dongho (red.). Current Trends in Altaic Linguistics. A Festschrift for Professor Emeritus Seong Baeg-in on his 80th 
Birthday. Seoul: Altaic Society of Korea, 523-545.

Jin, Junli. 2009. Chronological and Cultural Framework of Bronzes in

Northern China during the 4th to the 3rd Millennia B. P.. Tybinga:

Universität Tübingen.

Kelly, Jack. 2004. Gunpowder: Alchemy, Bombards, \& Pyrotechnics:

The History of the Explosive that Changed the World. Nowy Jork:

Basic Books.

Keyser, Christine, Caroline Bouakaze (i in.). 2009. Ancient DNA

Provides New Insights into the History of South Siberian Kurgan

People, Human Genetics 126, 395-410.

Lane, George. 2004. Genghis Khan and Mongol Rule. Westport:

Greenwood Publishing Group.

Lang, David Marshall. 1983. Bułgarzy: od czasów pogańskich do podboju przez Turcję Osmańska. Warszawa: Państwowy Instytut Wydawniczy.

Lebedynsky, Jaroslav. 2006. Les Saces - Les Nomades blancs d'Asie. Troyes: Errance Edition.

Lung, Rachel. 2011. Interpreters in Early Imperial China. Amsterdam: John Benjamins Publishing.

Mallory, James. 2010. Bronze Age Languages of the Tarim Basin, Expedition 52, 44-52.

Mallory, James, Victor Mair. 2000. The Tarim Mummies: Ancient China and the Mystery of the Earliest Peoples from the West. Londyn: Thames \& Hudson.

Matušenko, Vladimir. 1997. Западная Сибирь в системе древних культур Евразии, Вестник Омского университета 2, 43-46.

Mèanchen-Helfen, Otto. 1973. The World of the Huns: Studies in Their History and Culture. Los Angeles: University of California Press.

Mihailescu-Bîrliba, Lucrețiu. 2009. A Funerary Sculptured Monumentof Chester and its Representation, Studia Antiqua et Archaeologica XV, 146-173.

Needham, Joseph. 1986. Science \& Civilisation in China, Volume 7: The Gunpowder Epic. Cambridge: Cambridge University Press.

Nicolle, David. 1984. Arthur and the Anglo-Saxon Wars. Oxford: Osprey Publishing.

Simonenko, Oleksandr. 2012. On the Problem of the "HunsSarmatians", Anabasi. Studia Classica et Orientalia 3, 289-302.

Skripkin, Anatoly. 2003. Östliche und westliche Neuerungen in der materiellen Kultur der Sarmaten der europäischen Steppen in den ersten Jahrhunderten n. Chr.: Christian Radtke (red.). KontaktKooperation-Konflikt, Germanen und Sarmaten zwischen dem 1. und dem 4. Jahrhundrt nach Christus. Neumünster: Wachholtz, 9-18.

Svyatko, Svetlana, James Mallory (i in.). 2009. New Radiocarbon 
Dates and a Review of the Chronology of Prehistoric Populations from the Minusinsk Basin, Southern Siberia, Russia, Radiocarbon 1, 243-273.

Szymański, Wojciech. 1979. Awarzy: Wojciech Szymański, Elżbieta Dąbrowska (red.). Awarzy, Węgrzy. Wrocław, Warszawa: Wydawnictwo Polskiej Akademii Nauk, 7-121.

Świętosławski, Witold. 2001. Rola Awarów w rozpowszechnieniu w Europie azjatyckich form uzbrojenia, Acta Unieversitatis Lodziensis, Folia Archaeologica 23, 75-85.

Tatara, Antoni. 2012. Święty na piątkę, Niedziela 33, 21.

Vauchez, André, Richard Dobson (i in.). 2001. Encyclopedia of the Middle Ages. Oxford: Oxford University Press.

Xinjiang Uigur Autonomous Region Museum. 2006. Exibition Catalogue. Urumczi: Xinjiang Baishiyuan Craft and Art.

Xu, Shuhua, Wei Huang (i in.). 2008. Analysis of Genomic Admixture in Uyghur and Its Implication in Mapping Strategy, The American Journal of Human Genetics 82, 883-89.

Zerjal, Tatiana, Spencer Wells (i in.). 2002. A Genetic Landscape Reshaped by Recent Events: Y-Chromosomal Insights into Central Asia, The American Journal of Human Genetics 71, 466-482.

\section{Teksty źródłowe}

Biao, Ban, Ban Gu, Ban Zhao. The History of the Former Han Dynasty, Hànshū (前汉书), Vol. 3 [przeł. Homer H. Dubs]. Baltimore: Waverly, 1938-1955.

Prokopiusz z Cezarei. 1936. Wojna Wandalska (Bellum Vandalicum), Procopii Caesariensis Historiarum Temporis Sui Tetras Altera. De Bello Gothico. [przeł. Claudius Maltretus (Wenecja 1729)]: Przedruk w A Source Book for Medieval Economic History: Roy C. Cave, Herbert H. Coulson (red.). Milwaukee: The Bruce Publishing Co., 244-245.

Sima Qian (司马迁). 1993. Records of the Grand Historian (Shìjì, 史记), Records of the Grand Historian of China. Han Dynasty II, [przeł. Burton Watson]. Nowy Jork: Columbia University Press.

\section{Źródła internetowe}

Callaway, Ewen. 2013. Hominin DNA Baffles Experts, Nature, http://www.nature.com/news/hominin-dna-baffles-experts1.14294, dostęp: 10.04.2014. 
Everson, Michael, André Szelp. 2012. Consolidated Proposal for Encoding the Old Hungarian Script in the UCS, http://std.dkuug.dk/jtc1/sc2/wg2/docs/n4268.pdf, dostęp: 10.04.2014.

Li, Chunxiang, Hongjie Li (i in.). 2010. Evidence that a West-East Admixed Population Lived in the Tarim Basin as Early as the Early Bronze Age, BMC Biology 8, http://www.ncbi.nlm.nih.gov/pmc/articles/PMC2838831/, dostęp: 10.04.2014.

\begin{abstract}
The Role of Nomads of the Great Steppe in Transfer of Ideas between Europe and the Far East

This paper discusses the role of nomads in transfer of ideas between Western Eurasia and the Far East (understood as China and the Korean Peninsula). An ongoing contact between European and Central Asian cultures, constantly influenced by Chinese people, had started in the early Bronze Age and has continued until the Middle Ages, when the military power of Asiatic nomads decreased. This influence concerned not only inventions but also horse breeding, new vocabulary and cuisine. The majority of ideas spread only in one direction, from the Far East to Europe. The most famous of them were different types of weapon, such as a sword with annular pommel introduced in the Roman period or powder known from the 13th century, but also horse tack (for example stirrups) and dumplings. The influence of European culture on Asia is less visible, but it included chariots and probably the bronze treatment.
\end{abstract}

Keywords: China, Korea, Europe, nomads of the Great Steppe, transfer of ideas, inventions 